\title{
Catalytic Decomposition of Biomass Tars at Low-Temperature
}

\author{
Le Duc Dung, Kayoko Morishita and Takayuki Takarada
}

Additional information is available at the end of the chapter

http://dx.doi.org/10.5772/55356

\section{Introduction}

Tar is a viscous black liquid derived from pyrolysis of organic matter as well as a complex mixture of hydrocarbons. The presence of tar in product gas may cause blockage and corrosion of equipment and be responsible for fouling or reducing overall efficiency of processes. By far, tar removal is the most problematic during biomass gasification. Hence, the successful implementation of gasification technology for gas engine, gas turbine or fuel cell based power projects depends much on the effective and efficient removal or conversion of tar from the product gas. Beside that the catalytic steam reforming tar is one of the most promising methods to suppress the problems. Biomass product gas is usually low high heating value; therefore enhancement of product gas quality is other important target. We propose a research topic that use of nickel loaded brown coal char as a new catalyst for decomposing tar from biomass gasification in fluidized bed gasifier. The method is promising to achieve some advantages of low cost by use of low rank coal as catalyst support material, high catalyst activity and enhancement of product gas quality. Yallourn brown coal has been selected for preparing catalyst support. The coal is low rank with high moisture content, low heat value and high oxygen content. It is hard to use for generating energy. However, it has many outstanding features such as less ash and sulfur content, and including abundant of oxygen-containing functional groups such as carboxyl and phenol groups which are available for ion-exchange with metals. In this research work, a nickel loaded brown coal char (Ni/BCC) was prepared by ion-exchange method, dried at $380 \mathrm{~K}$ in nitrogen for $24 \mathrm{~h}$, and then pyrolysed at $923 \mathrm{~K}$ in nitrogen for $90 \mathrm{~min}$. The works have been carried out is that using nickel loaded brown coal to decompose tar in pyrolysis and steam gasification process. It was carried out in a two-stage fixed-bed reactor and a lab scale fluidized bed gasifier under mild conditions (temperature, steam, space velocity, operation time). Inside of gasifier is constructed by two beds, the primary one is a fluidized bed with sand, and the second one is a catalyst bed. The new catalyst has shown high catalytic 
activity and stable activity and given the high quality of product gas in presence of steam, approximately $90 \%$ of biomass tar was decomposed and useful gas components $\left(\mathrm{CH}_{4}, \mathrm{CO}\right.$, and $\mathrm{H}_{2}$ ) yields were higher than those of $\mathrm{Ni} / \mathrm{Al}_{2} \mathrm{O}_{3}$ catalyst. $\mathrm{Ni} / \mathrm{BCC}$ catalyst was characterized and exhibited good dispersion of nickel particles, ultra-fine Ni less than $15 \mathrm{~nm}$ and having a large surface area about $350 \mathrm{~m}^{2} / \mathrm{g}$. Moreover, at the end of catalyst life span, the catalyst can be disposed of simply by gasifying/burning the coal char, during which the energy value of the char support can be recovered. Also, the agglomerated nickel residues could be used as functional materials of powder metallurgy and battery development. The general results suggest that the $\mathrm{Ni} / \mathrm{BCC}$ catalyst offers a potential to be used as a tar steam reforming catalyst in biomass gasification.

\subsection{Tar and tar removal}

There are still many questions related to tar and the problems they may cause. Tar is a viscous black liquid derived from pyrolysis of organic matter as well as a complex mixture of hydrocarbons [1]. Various research groups are defining tar differently. In the EU/IEA/USDOE meeting on tar measurement protocol held in Brussels in the year 1998, it was agreed by a number of experts to define tar as all organic contaminants with a molecular weight larger than benzene [2]

The presence of tar in product gas may cause blockage and corrosion of equipment and be responsible for fouling or reducing overall efficiency of processes. Tar is formed when biomass is heated the molecular bonds of the biomass break; the smallest molecules gaseous, the larger molecules are called primary tars. These primary tars, which are always fragments of the original material, can react to secondary tars by further reactions at the same temperature and to tertiary tars at high temperature $[3,4,5,6]$ Figure 1 show tar is quite complex and hard to decompose. By far, tar removal is the most problematic during biomass gasification. Hence, the successful implementation of gasification technology for gas engine/turbine based power projects depends much on the effective and efficient removal/conversion of tar from the producer gas. Up to now, a great amount of work concerning tar reduction or reforming has been reported with abundant technologies to remove tar from biomass product gas.

J. Han, and H. Kim had divided tar removal methods into five groups: mechanical methods (using cyclone, filters ceramic), granular beds, Electrostatic precipitators and Scrubbers; selfmodification, selecting optimal operation parameters for gasifier or using a low tar gasifier; Catalytic cracking; Thermal cracking and Plasma methods [5]. The review shows that the primary use of mechanism methods is to capture the fly ash or particles from product gas; the effect on tar removal is also very good. However, these methods only remove or capture the tar from product gases, while the energy in tar is lost. The self-modification and other methods can not only reduce the tar but also convert the tar into useful gases. The selfmodification methods include: selecting better gasifer, and optimizing operation parameters. Tar reduced by modifying operation parameter is at the expense of reducing the heat value of gases. Catalyst cracking and thermal cracking are generally used to decompose or reduce tar though there are still some disadvantages. Plasma technology cannot only 


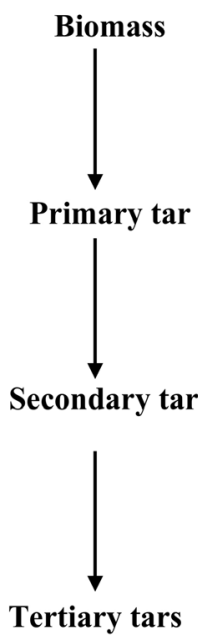

Original biomass chemical structures

(Celluloses, lignin starches, hemicelluloses etc.)

Very fast/ low temperature, $673 \mathrm{~K}$ to $973 \mathrm{~K}$

(Acids, Ketoses, phenols, guaiacols, furans...)

Fast/ everage temperature 973 to $1123 \mathrm{~K}$

(Phenols, Monoaromatic, Hydrocarbons...)

Slow/ high temperature 1123 to $2273 \mathrm{~K}$

PAH: 2-ring, 3- ring, 4-ring, 5-ring, 6-ring

Figure 1. Formation of biomass tars and compounds formed

effectively remove fly ash, $\mathrm{NOx}$ and $\mathrm{SO}_{2}$, but also sharply decrease the formation of tar during biomass gasification. In order to get highly efficient tar decomposition, the temperature of thermal cracking needs to be very high, which results in operating cost increase. Catalyst cracking can modify the composition of product gases at low temperature with high carbon conversion efficiency. Nevertheless, there still exists a short coming such as: the commercial Ni-based and alkali metal catalysts will be inactive by deposited carbon, and $\mathrm{H}_{2} \mathrm{~S}$. The newly developed novel catalyst can overcome the disadvantages by use of expensive metals $(\mathrm{Co}, \mathrm{Pt}, \mathrm{Ru}, \mathrm{Pd}$ and $\mathrm{Rh})$, and also catalyst supports $\left(\mathrm{Al}_{2} \mathrm{O}_{3}, \mathrm{Al}, \mathrm{SiO}, \mathrm{TiO}_{2}\right.$, $\mathrm{ZrO}_{2}, \mathrm{MgO}$ or $\mathrm{WO}_{3}$ ) and perform tar removal with high and stable activity even under the presence of high concentration of $\mathrm{H}_{2} \mathrm{~S}$ in some cases. In order to satisfying both high and stable activity and good price, the development of catalyst meets the need to be continuing.

\subsection{Catalysts}

Due to the advantages of converting tar into useful gases and adjusting the compositions of product gases, catalyst cracking has been of interest since the middle 1980s. The simplified mechanism for catalyst tar reforming can be described as follows [7-9]. First, methane or other hydrocarbons are dissociatively adsorbed onto a metal site where metal catalyzed dehydrogenation occurs. Water is also dissociatively adsorbed onto the ceramic support, hydroxylating the surface. At the appropriate temperature, the $\mathrm{OH}$ radicals migrate to the metal sites, leading to oxidation of the intermediate hydrocarbon fragments and surface carbon to $\mathrm{CO}+\mathrm{H}_{2}$. David $[9,10]$ summarized the criteria for catalyst as follows:

1. the catalysts must be effective in removing tar;

2. if the desired product was syngas, the catalysts must be capable of reforming methane;

3. The catalysts should provide a suitable syngas ratio for the intended process; 
4. the catalysts should be resistant to deactivation as a result of carbon fouling and sintering;

5. the catalysts should be easily regenerated.

6. The catalysts should be strong; and

7. the catalysts should be inexpensive.

Moulijn J.A. [11] has classified main causes of the deactivation into five reasons that are poisoning, fouling, thermal degradation (sintering, evaporation) initiated by the often high temperature, mechanical damage and corrosion/leaching by the reaction mixture. The deactivation phenomenon inside a catalyst particle is described on Figure 2 [11]. Among them, thermal degradation reason often occurs during catalyst reforming tar at relative high temperature (Figure 3).

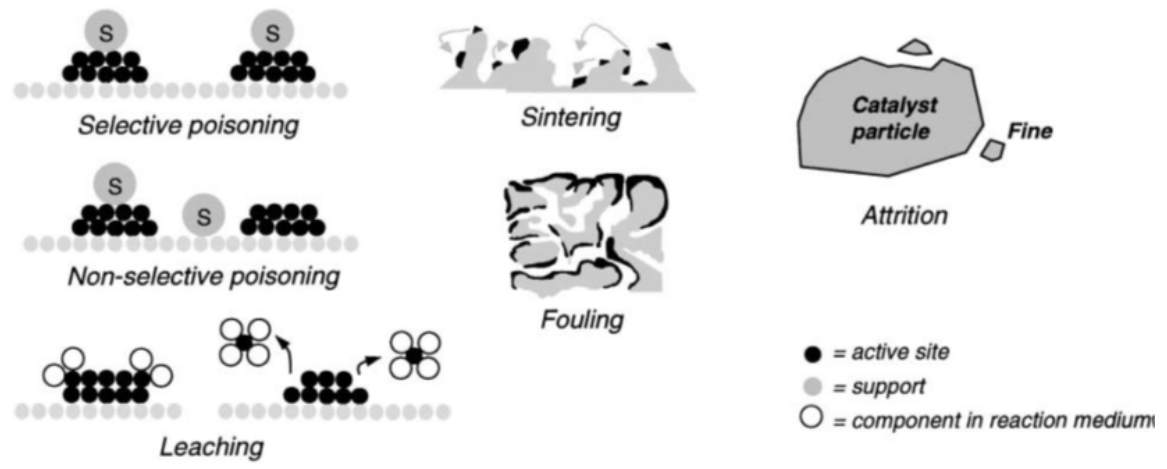

Figure 2. Major types of deactivation in heterogeneous catalysis

(a)

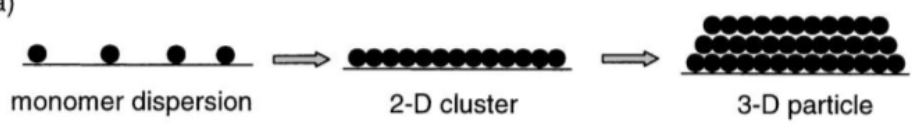

(b)

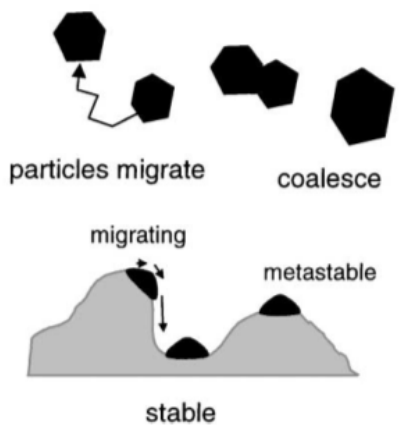

(c)

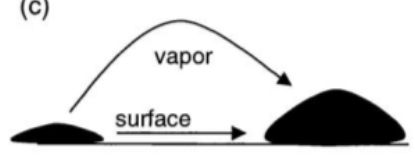

interparticle transport

Figure 3. Schematic of the various stages in the formation and growth of particles from monomer dispersion ((a): Clusters of atoms (or small metal particles); two-dimensional clusters, and; threedimensional particles; (b): Particles might move and coalesce; (c): Atoms move from one particle to another, either by volatilisation or by surface migration.) 


\section{Nikel based catalysts}

Nickel has been developed with various promoters and carriers for decomposing tar and tar models [7-27].

Zhang [13] investigated tar catalytic destruction in a tar conversion system consisting of a guard bed and catalytic reactor. Three Ni based catalysts (ICI46-1, Z409 and RZ409) were proven to be effective in eliminating heavy tars ( $99 \%$ destruction efficiency). The experimental results demonstrated that space velocity $(1500-6000)$ had little effect on gas compositions, while increasing temperature boosted hydrogen yield and reduced light hydrocarbons $\left(\mathrm{CH}_{4}\right.$ and $\left.\mathrm{C}_{2} \mathrm{H}_{4}\right)$ formation, which suggested that tar decomposition was controlled by chemical kinetics.

Furusawa et al. [14] reported that $10 \mathrm{wt} \% \mathrm{Ni} / \mathrm{MgO}(873 \mathrm{~K})$ catalyst showed the best performance. Nickel supported on silica was active for tar catalyst cracking methane at relatively low temperature $(823 \mathrm{~K})$ was described by Zhang [9].

Srinakruang et al.[15,16] has developed Ni/Dolomite as highly efficient sulphur and coking resistance catalyst, and reported that calcining at $500{ }^{\circ} \mathrm{C}$ exhibited the most effective catalyst among $\mathrm{Ni} / \mathrm{SiO}_{2}$ and $\mathrm{Ni} / \mathrm{Al}_{2} \mathrm{O}_{3}$; the poisoning effect was enhanced by increasing the reaction temperature and steam/C ratio; higher activity, durability and coking resistance.

Sato et al. [17], has developed $\mathrm{Ni}-\mathrm{WO}_{3} / \mathrm{MgO}-\mathrm{CaO}$ catalyst for naphthalene and toluene reforming. The results exhibited a better resistance to sulfur and coking catalyst; tar reforming to better than $90 \%$ and $100 \mathrm{~h}$ steady tar reforming operation (in $\mathrm{H}_{2} \mathrm{~S}$ ) at 800 $850^{\circ} \mathrm{C}$.

Dou et al.[18] compared five catalysts on tar removal from fuel gases in a fixed-bed reactor. The Y-zeolite and NiMo catalysts were found to be the most effective about $100 \%$ tar removal can be achieved at $550{ }^{\circ} \mathrm{C}$. It was also observed that process variables like temperature and space velocity had very significant effect on tar removal.

Baker [19] also mentioned the phenomena in their experiments. In order to overcome the shortcoming of the commercial Ni-based catalyst, many Ni-based catalysts were developed.

Miyazawa et al. [20] has prepared $\mathrm{Ni}\left(\mathrm{Ni} / \mathrm{Al}_{2} \mathrm{O}_{3}, \mathrm{Ni} / \mathrm{ZrO}_{2}, \mathrm{Ni} / \mathrm{TiO}_{2}, \mathrm{Ni} / \mathrm{CeO}_{2}\right.$ and $\left.\mathrm{Ni} / \mathrm{MgO}\right)$ catalyst to reformed tar in the partial oxidation (POT) and steam introduction. Results have been achieved: the order of the performance at $823 \mathrm{~K}$ was as follows: $\mathrm{Ni} / \mathrm{Al}_{2} \mathrm{O}_{3}>\mathrm{Ni} / \mathrm{ZrO}_{2}>$ $\mathrm{Ni} / \mathrm{TiO}_{2}>\mathrm{Ni} / \mathrm{CeO}_{2}>\mathrm{Ni} / \mathrm{MgO}>$ no catalyst; $\mathrm{Ni} / \mathrm{CeO}_{2}$ showed smaller amount of coke than other catalysts; in the POT, much higher tar conversion and lower coke yield were obtained than that in SRT using fixed bed reactor.

\subsection{Catalytic brown coal gasification}

It is very important to increase the thermal efficiency of coal conversion for not only protecting the limited coal resources but also reducing $\mathrm{CO}_{2}$ and air pollutant emission. Steam gasification of coal is one of the most promising energy conversion technologies for producing hydrogen. 


\section{Brown Coal}

Brown coal or lignite is a low rank with high moisture content of around $60 \%$, low heat value and high oxygen content. Therefore, it is hard to use for converted to useful energy. However, it is concluding many outstanding features such as less ash and sulfur content, and especially, including abundant of oxygen-containing functional groups such as carboxyl and phenol groups which are available for ion-exchange with metals. The structural unit of coal models is shown in Figure $4 \mathrm{~d}$.

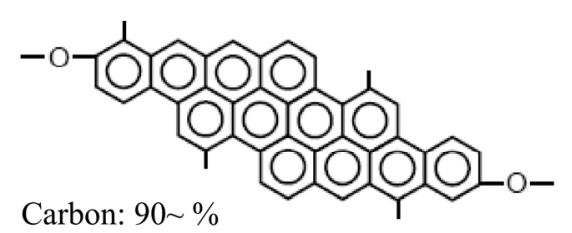

(a)

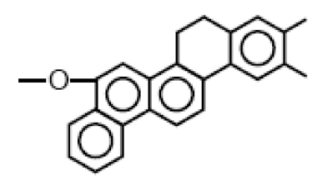

Carbon: $83 \sim 90 \%$<smiles>CC1=C(O)Cc2c(O)cc3c(c2C1C)CC(O)CC3C</smiles>

Carbon: $78 \sim 83 \%$

(c)

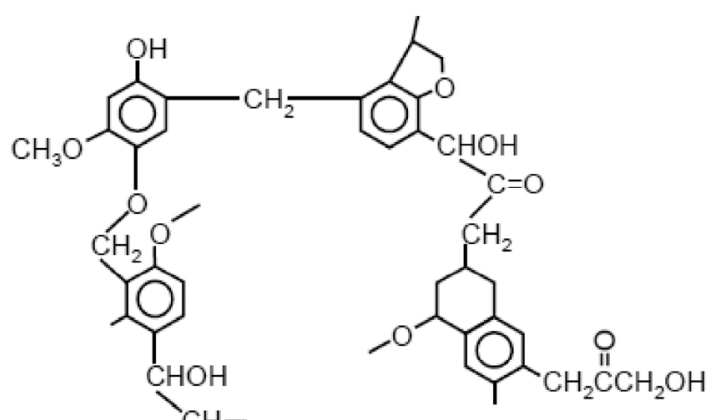

Carbon: $70 \sim 78 \%$

Figure 4. Structural unit of coal models (a: anthracite coal; b: bituminous coal; c: bituminous coal; d: brown coal)

\section{Catalytic coal gasification}

Tomita [21, 22] has reported low temperature gasification of Yallourn coal catalysed by nickel. By the different way of prepared catalyst as usual like conventional impregnation methods, coal was mixed with an aqueous solution of hexamine nickel carbonate. This mixture gave a perfect homogeneous, catalyst bearing coal. Analysis product gas he found that the gases in the rapid stage of char gasification at $723 \mathrm{~K}$ presented mainly hydrogen and carbon dioxide. The study demonstrates the first time that nickel catalyst can enhance gasification reactivity in a similar manner as observed for activate carbon.

Tomita [23, 24] continued to carry out nickel brown coal gasification with various gasification conditions such as amount weight of nickel loaded on coal, various 
temperatures. The good results exhibited carbon conversion reached $85 \%$, with $30 \mathrm{~min}$ for steam gasification at low temperature as $723 \mathrm{~K}$.

Ohtsuka [25] reported calcium catalysed steam gasification of Yallourn brown coal with the same way of preparation catalyst as Tomita have done. The results also showed that high activity for calcium catalyst steam gasification of brown coal.

Takarada [26] investigated catalyst steam gasification of coal by mixing of K-exchange brown coal. The results gave evident that rate of enhancement of $\mathrm{K}$-exchange Yallourn coal by physical mixing method is independent of the caking property of higher rank coal; Potassium is a highly suitable catalyst for catalytic gasification.

Recently, Miki [27] also carried out pyrolysis and gasification of coal which was loaded Ni by ion- exchanged method, and again proved nickel loaded brown coal has a high activity in coal gasification.

\section{Nickel catalyst preparation}

\section{1. $\mathrm{Ni} / \mathrm{BCC}$ catalyst}

The procedure of ion exchange is shown in Figure 5 and Figure 6. Yallourn (YL) coal char was used as catalyst support. YL coal (Australian brown coal) received in the form of briquettes. The coal was crushed, sieved to a particle size range of $1-2 \mathrm{~mm}$ in diameter, and then dried at $380 \mathrm{~K}$ for $12 \mathrm{~h}$. The nickel addition to the coal matrix was achieved by ionexchange with a solution of basic hexa ammine nickel carbonate $\left(\mathrm{NH}_{3}\right)_{6} \mathrm{NiCO}_{3}$ (Figure 5, 6). The coal was mixed with the $\left(\mathrm{NH}_{3}\right)_{6} \mathrm{NiCO}_{3}$ solution for $24 \mathrm{~h}$ and then recovered by filtration. The recovered solid was washed with distilled water and filtered again. Then, the washed solid was dried under $\mathrm{N}_{2}$ flow at $380 \mathrm{~K}$ for $24 \mathrm{~h}$. Last, raw catalysts were produced.

Catalysts was characterized by powder X-ray diffraction on XRD; M03XHF22, Mac Science Co., Ltd, using $\mathrm{CuK} \alpha$ radiation $(40 \mathrm{kV}, 30 \mathrm{~mA})$ in order to identify the potential evolution of the crystalline phases during catalyst pyrolysis tests. The diffractograms were recorded a step time of $10 \mathrm{sec}$. SEM analysis was applied to study the surface structure of Ni/BCC catalyst (FE-SEM; JSM-6700F, JEOL Datum Ltd.). An atomic absorption flame emission spectrophotometer (AA-6400F, Shimadzu Corp.) was used to examine the amount of $\mathrm{Ni}$ on raw $\mathrm{Ni} / \mathrm{BCC}$ (Ni $9 \pm 1 \%$-dry). After pyrolyzing with nitrogen gas at $923 \mathrm{~K}$ for 90 , its weigh loss is approximately $54 \%$, and therefore, nickel loaded in coal char could be estimated $19.6 \pm 2 \%$-char base. The intimacy of the contact between coal char and catalyst was so effective that the reactivity was considerably higher than those prepared by a conventional impregnation method [21-24]. Nitrogen adsorption characterization of catalysts was performed on equipment for automatic gas and vapor adsorption measurement (BELSORP-max, BEL Japan Co. Ltd.). Prior to adsorption measurement, the catalysts were degassed at $573 \mathrm{~K}$ for $3 \mathrm{~h}$ under a dynamic vacuum. The surface areas of fresh catalysts $(\mathrm{Ni} / \mathrm{BCC})$, which were obtained after pyrolysis of raw $\mathrm{Ni} / \mathrm{BCC}$ at $923 \mathrm{~K}$ for $90 \mathrm{~min}$ is $350 \mathrm{~m}^{2} / \mathrm{g}[28,29]$. 
$\mathrm{NiCO}_{3} 2 \mathrm{Ni}(\mathrm{OH})_{2} 4 \mathrm{H}_{2} \mathrm{O},\left(\mathrm{NH}_{4}\right)_{2} \mathrm{CO}_{3}$, Ammonia solution and distilled water
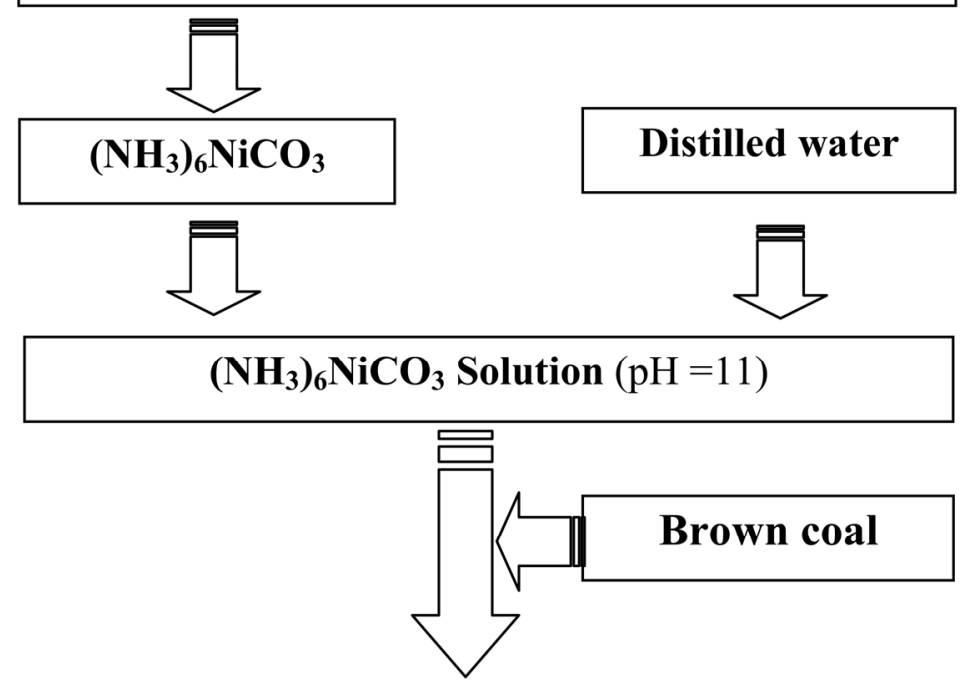

Stirring $(24 \mathrm{~h})$
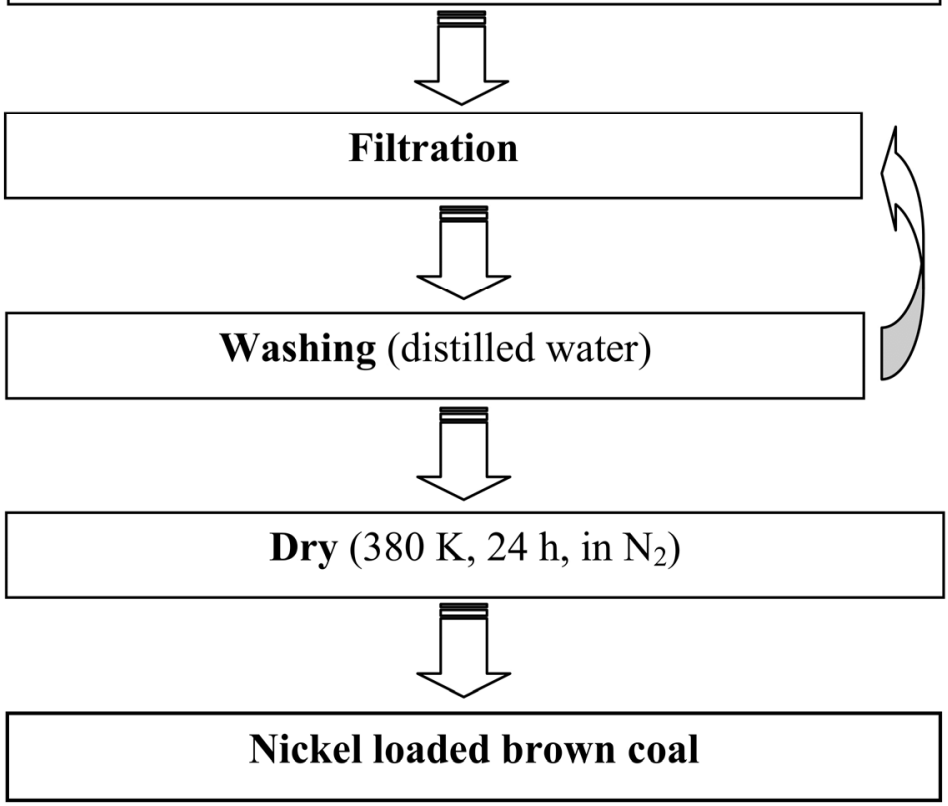

Figure 5. Schematic flow diagram of nickel and brown coal ion-exchange procedure 


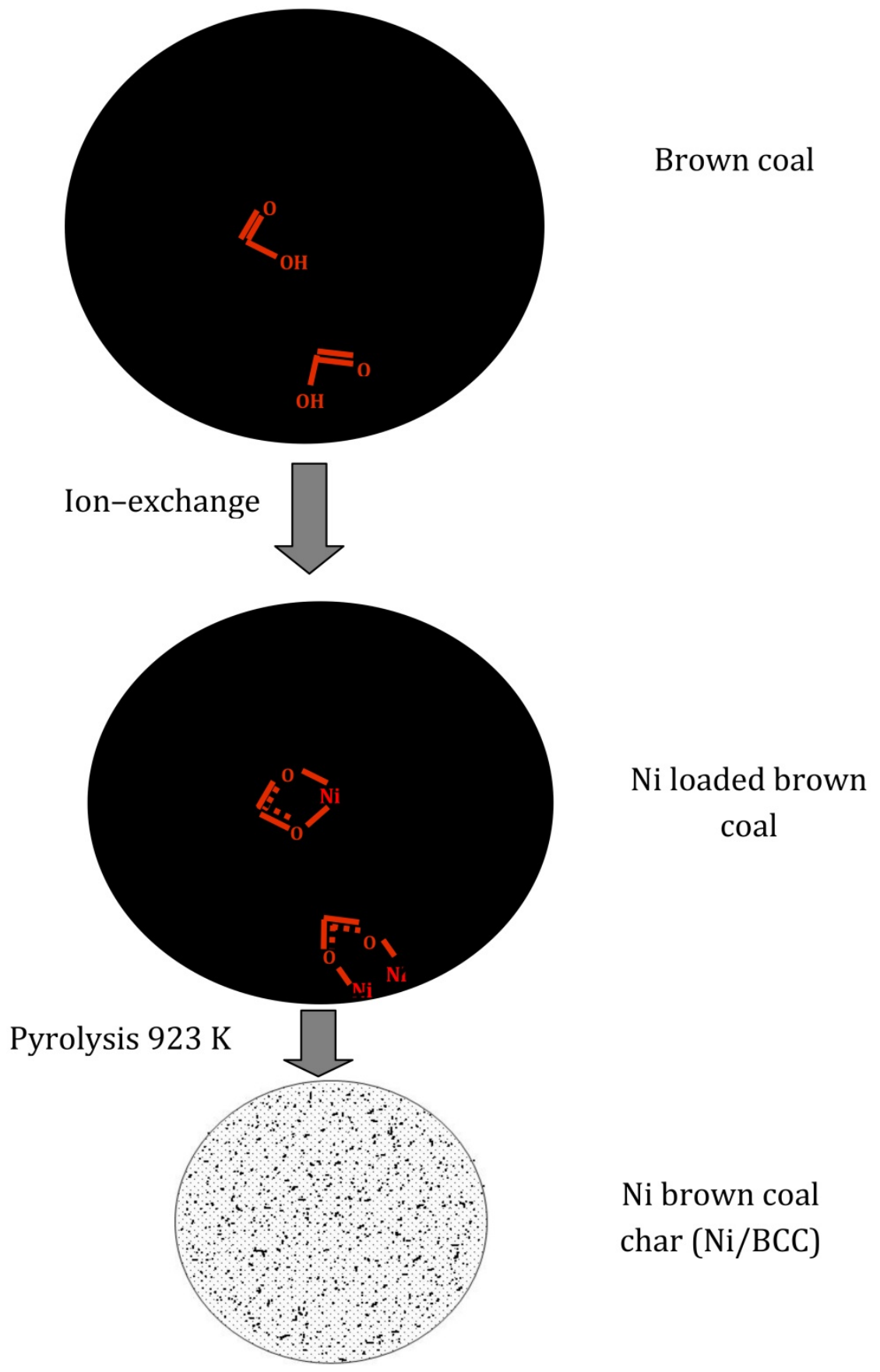

Figure 6. schematic diagram of nickel loaded brown coal char with structure unit of Ni/BCC. 


\section{2. $\mathrm{Ni} / \mathrm{Al}_{2} \mathrm{O}_{3}$ catalyst}

A conventional nickel catalyst (No.C13-4, Ni 20 \pm 2 wt \% SÜD-CHEMIE CATALYSTS JAPAN, Inc.) that was supported with alumina was also used to compare with $\mathrm{Ni} / \mathrm{BCC}$ catalyst. It was crushed and sieved to the fraction of $0.5-1 \mathrm{~mm}$.

\section{Catalytic decomposition of tar from woody biomass pyrolysis}

Pyrolysis is an important process in energy recovery from biomass and also as a previous stage to other processes such as gasification. Valuable gases, such as $\mathrm{H}_{2}$ and $\mathrm{CO}$, can also be generated by pyrolysis. These gases can be useful, among other applications, in chemical synthesis and high efficiency combustion systems such as fuel cells.

The hydrogen-rich product gas from biomass pyrolysis is believed to become a valuable energy source with natural carbon dioxide. However, biomass has low energy density, so the enhancement of the product gas quality from biomass gasification is necessary. Beside a particular problem which has not been completely solved so far is tar formation. Catalytic processes are considered as the most promising method with the highest potential to contribute a solution to this problem. Temperature is an important variable in thermal decomposition processes of biomass, significantly influencing the product distribution. Pyrolysis is an endothermic process, and the use of low temperatures in this process decreases the input energy for a system that is very positive from an energetic point of view and the system operation is easier than high temperature systems.

For both catalytic activity and economic reason, a nickel catalyst is the most suitable choice and the most widely used in the industry among metals like $\mathrm{Co}, \mathrm{Pt}, \mathrm{Ru}$ and $\mathrm{Rh}$, which were investigated by many authors [10,17-23]. Moreover, nickel based catalysts are reported to be quite effective not only for tar reduction, but also for decreasing the amount of nitrogenous compounds such as ammonia [24]. In most reports, conventional nickel catalysts, which had been developed for steam tar reforming, were tested [6,9,13,15,25,26]. However, the investigations are still limited because of coking $[19,22]$ or the use of expensive materials as catalyst supports $\left(\mathrm{CeO}_{2}, \mathrm{Al}_{2} \mathrm{O}_{3}, \mathrm{Al}, \mathrm{SiO}_{2}, \mathrm{TiO}_{2}, \mathrm{ZrO}_{2}, \mathrm{MgO}\right.$ or $\left.\mathrm{WO}_{3}\right)$. Among the above investigations, the most interesting one concerning the current study is brown coal gasification by the addition of a nickel catalyst in fluidized bed gasification at low temperature [21-23]. However, nickel catalyst has only been used for coal gasification itself.

To satisfy both high quality of product gas and use of a cheaper catalyst support (brown coal char), in this study, nickel loaded brown coal char catalyst has been developed for the new purpose of decomposing tarry material from woody biomass pyrolysis. A suitable temperature for catalytic tar decomposition was investigated in a two-stage fixed bed reactor. The effect of temperature on gas yield and carbon conversion have been discussed in detail and compared in the case of non catalyst and Ni/BCC catalyst. The better temperature is a reference result, being used in fluidized bed gasification which is available for continuous tests to assess durability. Catalytic activity was tested, evaluated by woody biomass pyrolysis in a fluidized bed gasifier for both of $\mathrm{Ni} / \mathrm{BCC}$ and reference catalyst 
$\mathrm{Ni} / \mathrm{Al}_{2} \mathrm{O}_{3}$. In a lab scale fluidized bed gasifier (FBG) Experiments, inside of FBG reactor is constructed by two beds, the primary one is a fluidized bed with sand where biomass was fed to produce tar, and the other is a catalyst bed that is used to evaluate and to compare catalytic activity between the new catalyst and a conventional $\mathrm{Ni} / \mathrm{Al}_{2} \mathrm{O}_{3}$ catalyst. The $\mathrm{Ni} / \mathrm{BCC}$ catalyst is prepared by ion exchange method, dried at $380 \mathrm{~K}$ in nitrogen for $24 \mathrm{~h}$, and is then calcined at $923 \mathrm{~K}$ in nitrogen for $90 \mathrm{~min}$. Sample for characterization of catalyst was prepared on the fixed-bed reactor under various conditions such as nickel loaded brown coal particle size range of 0.5 to $2 \mathrm{~mm}$, pyrolysis temperature range of 823 to $1023 \mathrm{~K}$ that are needed to investigate the effect both of catalyst particle size and pyrolysis temperature on crystallite size of $\mathrm{Ni} / \mathrm{BCC}$. The temperature as a function of gas yield and stable activity of catalyst absence of steam are investigated in this chapter.

\subsection{Experimental facilities}

\section{The two-stage fixed-bed quartz reactor}

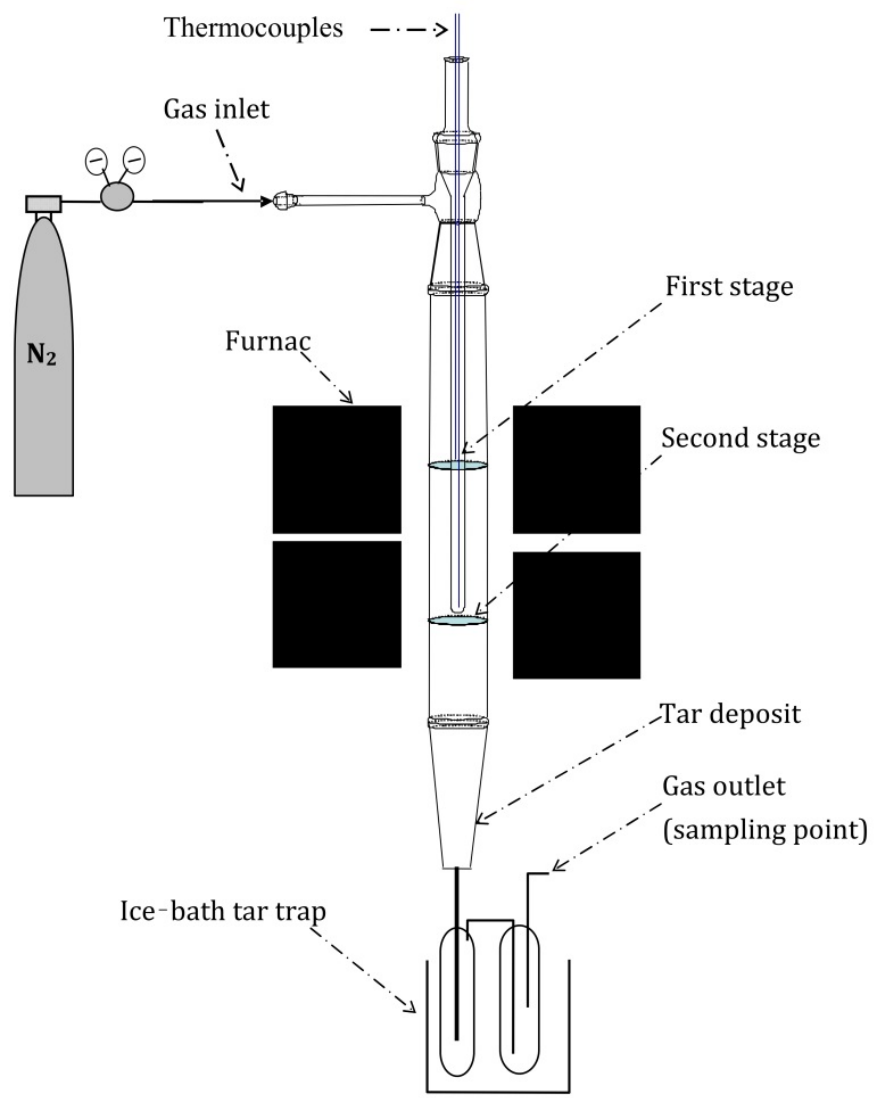

Figure 7. Schematic flow diagram of the two - stage fixed - bed quartz reactor 


\section{The fluidized bed gasifier}

The fluidized bed gasifier

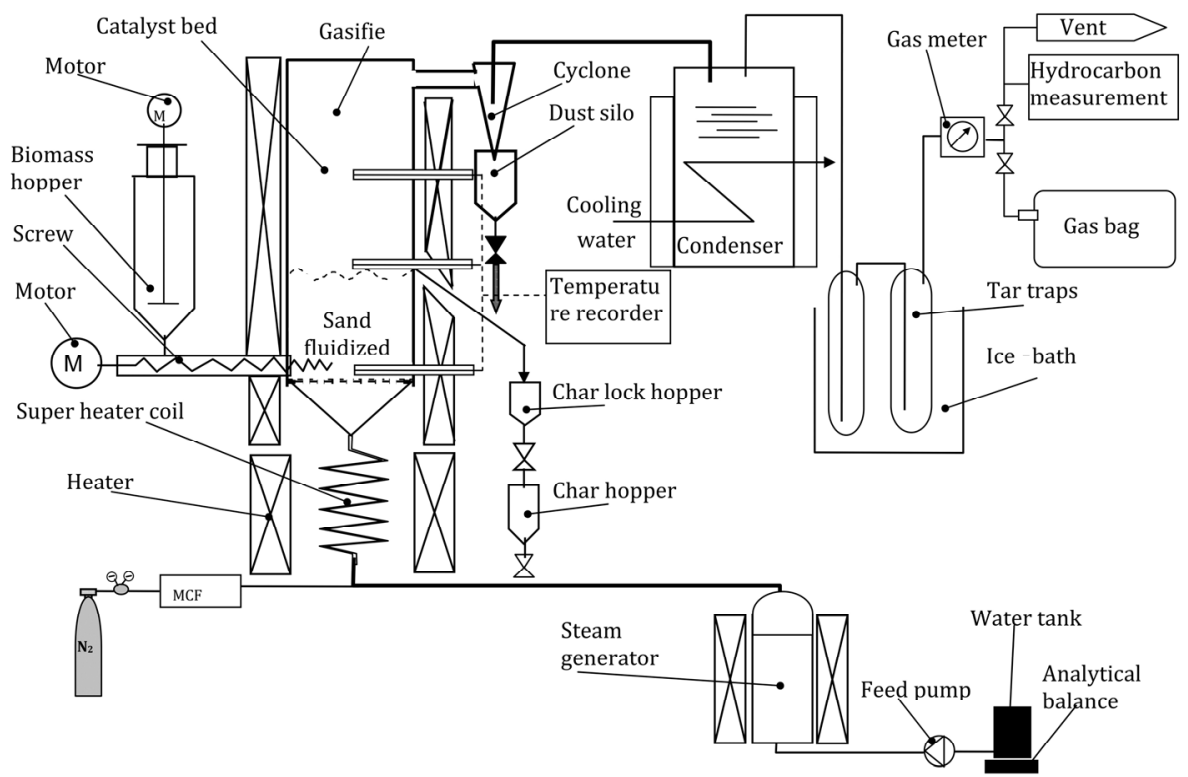

Figure 8. Schematic flow diagram of fluidized bed gasifier

\subsection{Results and discussion}

\subsubsection{Catalyst Evaluation in a Two-stage Fixed-bed Reactor}

Figure 9 illustrates the gas yield and the biomass carbon balance of woody red pine pyrolysis in a two fixed-bed quartz reactor. In the case Ni/BCC catalyst, total gas yield increased drastically at a catalyst bed temperature of $923 \mathrm{~K}$, at which the yield of $\mathrm{CO}$ and $\mathrm{H}_{2}$ achieved was 21.2 and 29.5 [mmol/g-sample daf], respectively, approximately three and six times in comparison to sand (Figure 9(a)). It was considered that tarry material was efficiently decomposed by the $\mathrm{Ni} / \mathrm{BCC}$ catalyst. If we consider the effect of catalytic pyrolysis temperature on gas yield, Figure 9 (a) also shows that the gas yield increased by increasing temperature from 823 to $923 \mathrm{~K}$, thus suggesting tar decomposition can be controlled by chemical kinetics.

Although there was no direct measurement of tar, we have the biomass carbon balance, which is illustrated in Figure 9(b). Among total carbon in biomass, percentages of carbon in product gas ( $\mathrm{C}_{-}$gas) and carbon in char (C_char) could be obtained by analyzing product gas and product char, respectively. Carbon in tar (C_tar) was estimated fairly by a different method: $C_{-}$tar $=100-\left(C_{-}\right.$gas $+C_{-}$char $)$. In the case of Ni/BCC, we could assume that the total carbon of product gas was released from biomass pyrolysis because the pyrolysis time 


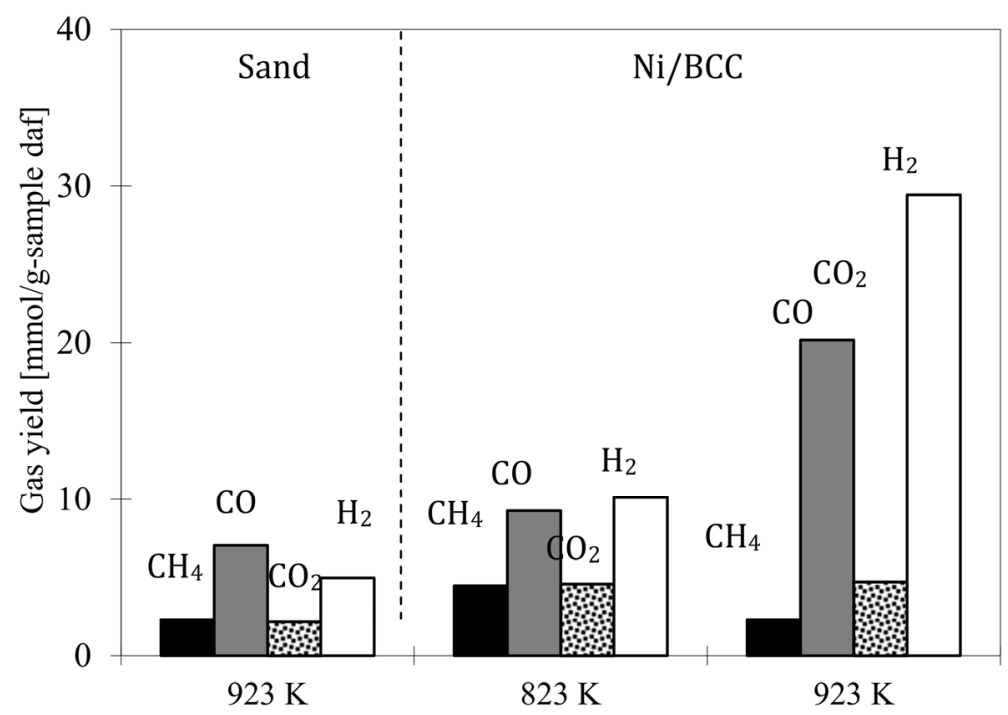

(a)

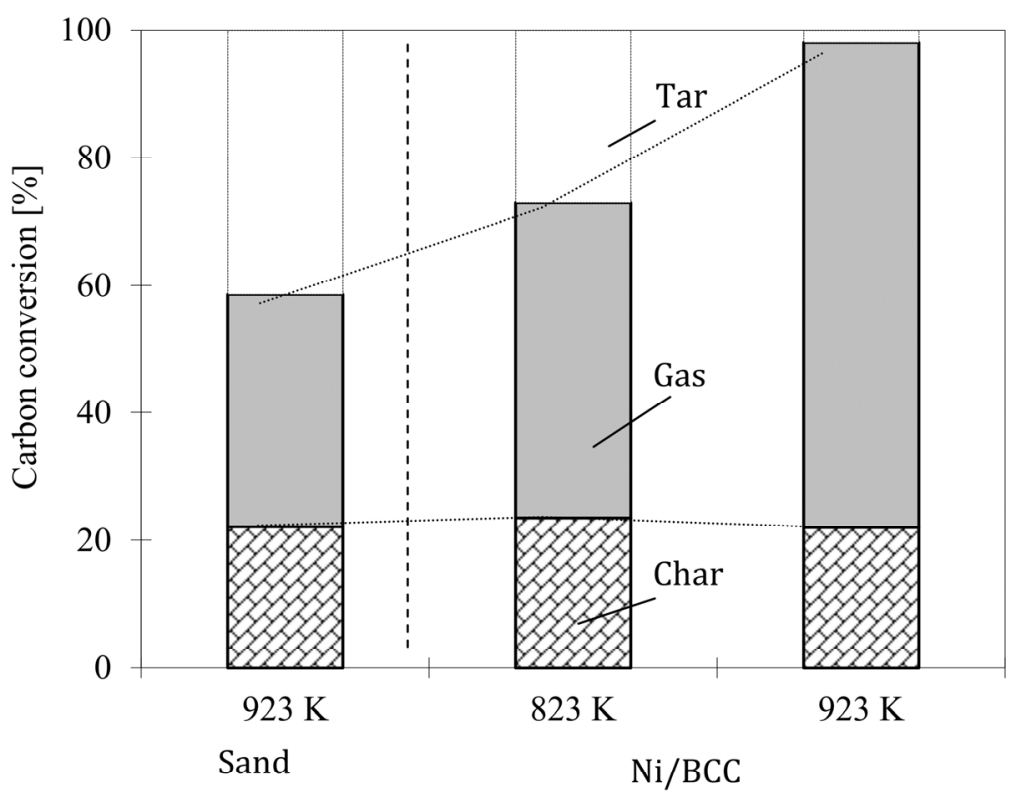

(b)

Figure 9. Effect of temperature on catalyst pyrolysis: (a) gas yields and (b) biomass carbon balance (space velocity 3000) 
of $90 \mathrm{~min}$ was enough to release most releasable carbon in Ni/BCC at $923 \mathrm{~K}$. The amount of C_chars was almost constant in all cases, because the char is accumulated in the first bed without contacting the catalyst particles at the same temperature of $1173 \mathrm{~K}$. In the case of catalytic tar decomposition, the amount of C_gas increased drastically compared to no catalyst at $923 \mathrm{~K}$. That is to say, the tar was decomposed over Ni/BCC catalyst by Equation, Tar $\rightarrow \mathrm{CO}+\mathrm{H}_{2}+\mathrm{CO}_{2}+\mathrm{CH}_{4}+\mathrm{C}_{2} \mathrm{H}_{4}+$ other hydrocarbon.

When using Ni/BCC catalyst, C_tar approaches zero at $923 \mathrm{~K}$. Moreover, we did not observe tar adhered on the reactor. Thus, it suggests almost all of the tar was decomposed at $923 \mathrm{~K}$ under the pyrolysis experimental conditions.

\subsubsection{Catalyst Evaluation in a Fluidized Bed Gasifer}

In the catalytic activity tests, the formation of products were observed for $60 \mathrm{~min}$, and significant heavy tar was not observed on the pipeline and tar traps. All experiments were performed at $923 \mathrm{~K}$ under nitrogen carry gas, space velocity 11000 . All calculated results of gas yield and C_gas were the average of specific results from various specific sampling times, which started at $10 \mathrm{~min}$ after feeding biomass and then in $20 \mathrm{~min}$ intervals. The effects of the catalyst on gas yields $\left(\mathrm{CH}_{4}, \mathrm{CO}, \mathrm{CO}_{2}, \mathrm{H}_{2}\right.$ yield) are illustrated in Figure 10 (a). The bars from left to right show the results for non-catalyst, $\mathrm{Ni} / \mathrm{Al}_{2} \mathrm{O}_{3}$ and $\mathrm{Ni} / \mathrm{BCC}$ catalyst. Using $\mathrm{Ni} / \mathrm{BCC}$ catalyst, $\mathrm{CH}_{4}, \mathrm{CO}, \mathrm{CO}_{2}$ and $\mathrm{H}_{2}$ yields were almost the same as those of $\mathrm{Ni} / \mathrm{Al}_{2} \mathrm{O}_{3}: 2.8$, 15.6, 6.3, 23.1 [mmol/g-sample daf], respectively. Especially, both $\mathrm{CO}$ and $\mathrm{CO}_{2}$ yields increased drastically by 2 times and $\mathrm{H}_{2}$ by approximately 5 times compared to those of noncatalyst. This result indicates that Ni catalysts are quite effective to decompose tar to useful gases such as $\mathrm{CO}$ and hydrogen.

Biomass carbon balance is illustrated in Figure 10 (b). A detailed carbon balance could not be carried out because of difficulty in accurately estimating the tar yield. In a similar way as described above section, we defined C_gas, C_char, C_coke (Deposited carbon on the catalyst) and calculated C_tar:

$$
C_{-} \text {tar }=100-\left(C_{-} \text {gas }+C_{-} \text {char }+C_{-}\right. \text {coke. }
$$

In the case of no catalyst, $C_{-}$coke was not observed at all, because coke is assigned to the carbon deposited on the catalyst surface. For the case Ni/BCC catalyst, C_coke was estimated by the difference of carbon in fresh $\mathrm{Ni} / \mathrm{BCC}$ and carbon in used Ni/BCC catalyst. The amount of C_char was almost constant in all of the cases. This is because the char is accumulated in the fluidized bed without contacting the catalyst particles. In the case of catalytic tar decomposition, the amount of C_gas increased drastically compared to no catalyst. The blank on the top of each bar in Figure 10(b) can be considered as a percentage of $\mathrm{C}_{-}$tar. For $\mathrm{Ni} / \mathrm{BCC}$ and $\mathrm{Ni} / \mathrm{Al}_{2} \mathrm{O}_{3}$ catalysts, $\mathrm{C}_{-}$tar was 12.3 and $8.9 \%$ and $\mathrm{C}_{-}$gas was 54.9 and $55.1 \%$, respectively. The results show that the Ni/BCC catalyst could not perform as well as the $\mathrm{Ni} / \mathrm{Al}_{2} \mathrm{O}_{3}$ catalyst to decompose tar under pyrolysis process. This result might be affected by a part of the deposited carbon being on some of the reactive surface of the $\mathrm{Ni}$ catalyst, while the raw $\mathrm{Ni} / \mathrm{BCC}$ catalyst was calcined due to volatile release from the brown coal. However, the results show that both catalysts are quite active to decompose tar. 


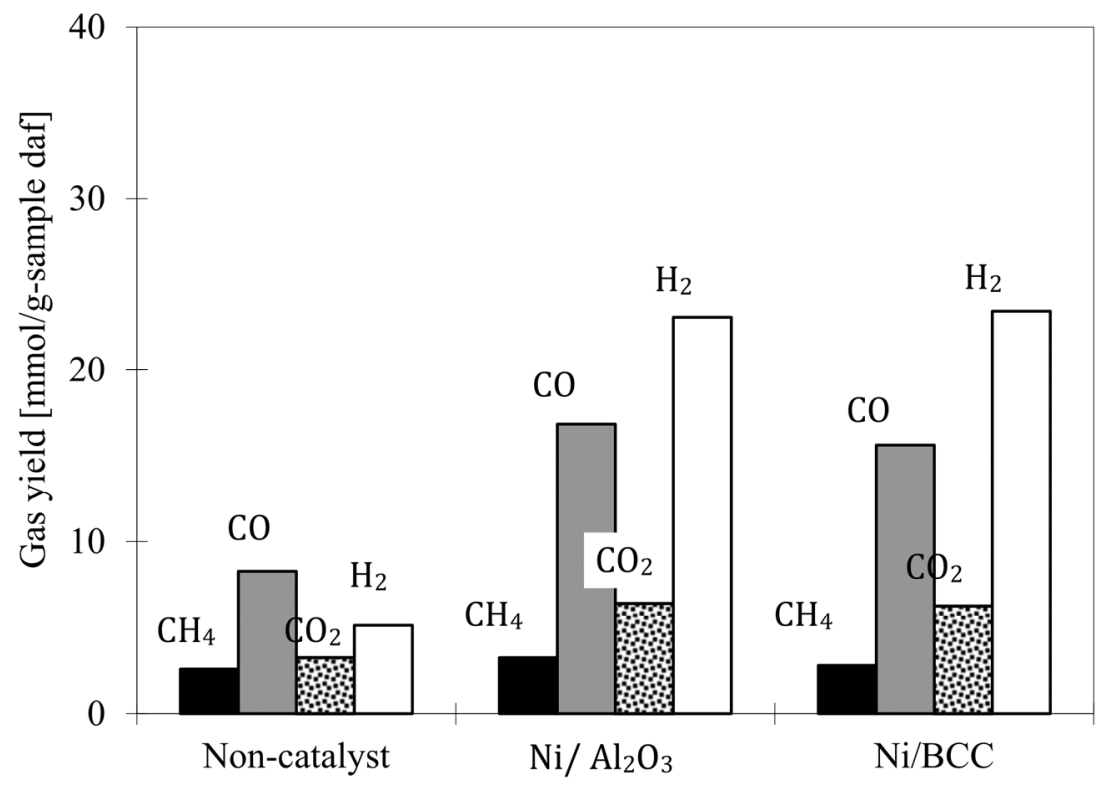

(a)

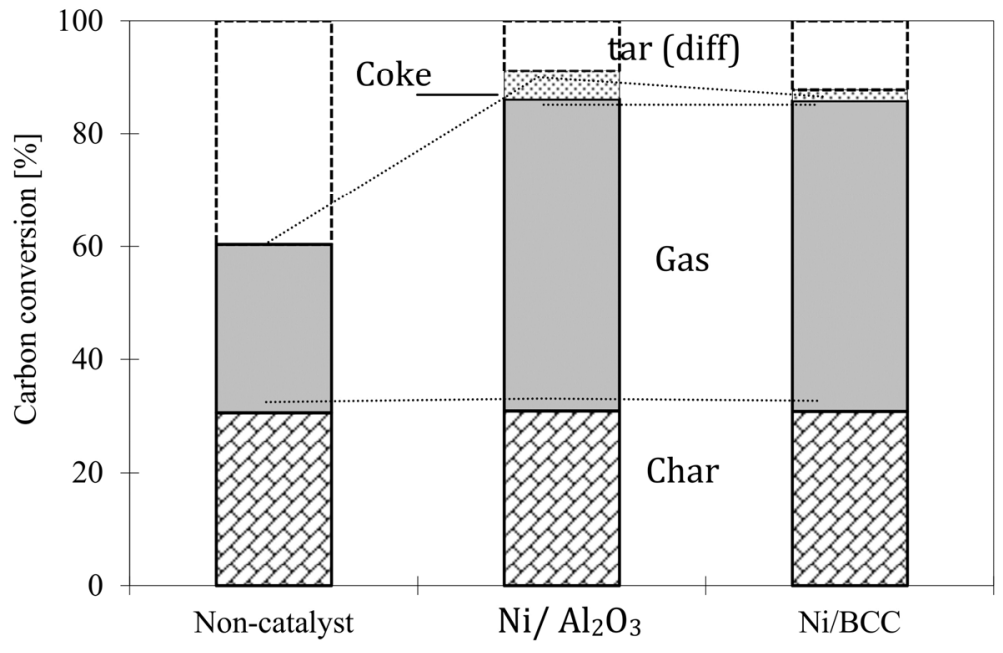

(b)

Figure 10. Comparison of different catalysts and non-catalyst without steam: (a) gas yields and (b) biomass carbon balance at $923 \mathrm{~K}$ and no steam $(923 \mathrm{~K}, \mathrm{sv}=11000)$ 


\section{Catalytic steam reforming tar from woody biomass gasification}

The aim of current study is to increase the coking resistance ability as well as steam gasification of deposited carbon on $\mathrm{Ni} / \mathrm{BCC}$ catalyst. It was available to regenerate activity of catalyst. By the way, product gases propose to achieve an enhancement of the product gas quality by not only recovering energy from tar reforming but also addition by-product gas from steam gasification of the $\mathrm{Ni} / \mathrm{BCC}$ char at relative low temperature. To decompose tar of biomass gasification by the use of $\mathrm{Ni} / \mathrm{BCC}$ catalyst has been investigated under mild conditions in a laboratory scale fluidized bed gasifier with introducing steam as a gasifying agent and nitrogen as the product gas carrier. A conventional $\mathrm{Ni} / \mathrm{Al}_{2} \mathrm{O}_{3}$ catalyst also was selected to compare with the $\mathrm{Ni} / \mathrm{BCC}$ catalyst in the presence of steam. In this study, the $\mathrm{Ni} / \mathrm{BCC}$ catalyst was consumed at different steam feed rate so as determine the effect of steam feed rate on the crystallite size of catalyst; catalytic tar reforming temperature, the space velocity as a function of the gas yield and biomass carbon conversions in fluidized bed gasifier were investigated. The product gas components was discussed in detail and compared between both cases of the absent of steam and the presence of steam.

\subsection{Discussion of catalytic steam tar reforming pathway}

Figure 11 shows simple pathway of the woody biomass gasification process with Ni/BCC catalyst. The woody biomass was first pyrolysis to form gas, tar and char at $923 \mathrm{~K}$. Both useful gas and tar passed through the catalyst particles. Tar was dissociatively adsorbed onto a nickel site where nickel catalyzed dehydrogenation occurs. With steam injection tar would be cracked and reformed follow the mechanism.

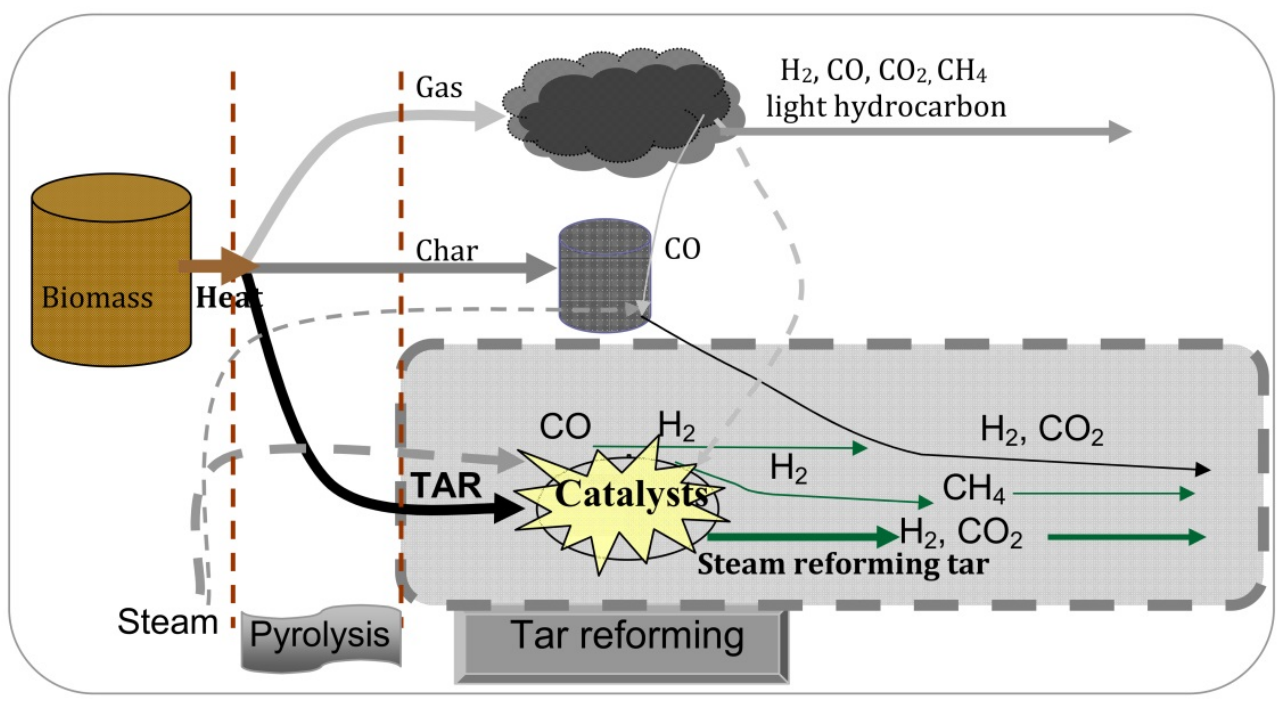

Figure 11. Schematic pathway of biomass pyrolysis and tar reforming using Ni/BCC catalyst 
The chemistry of coal (biomass) gasification is usually depicted to involve the following reactions of carbon and steam [29]. The standard enthalpy change (gram molecules) at $298 \mathrm{~K}$ is shown for each reaction. The most important reactions are listed in Table 1[29-31]

\begin{tabular}{|c|c|c|}
\hline Process & $\Delta_{H_{298}^{O}}^{O}(\mathrm{~kJ} / \mathrm{mol})$ & \\
\hline \multicolumn{3}{|l|}{ Steam reforming } \\
\hline $\mathrm{CH}_{4}+\mathrm{H}_{2} \mathrm{O}=\mathrm{CO}+3 \mathrm{H}_{2}$ & +206 & $(7-1)$ \\
\hline $\mathrm{C} n \mathrm{H} m+n \mathrm{H}_{2} \mathrm{O}=n \mathrm{CO}+n+(m / 2) \mathrm{H}_{2}$ & $+1175^{\mathrm{a}}$ & $(7-2)$ \\
\hline \multicolumn{3}{|l|}{$\mathrm{CO}_{2}$ reforming } \\
\hline $\mathrm{CH}_{4}+\mathrm{CO}_{2}=2 \mathrm{CO}+2 \mathrm{H}_{2}$ & +247 & $(7-3)$ \\
\hline \multicolumn{3}{|l|}{ Gasification } \\
\hline $\mathrm{C}+\mathrm{H}_{2} \mathrm{O} \rightarrow \mathrm{CO}+\mathrm{H}_{2}$ & +131.3 & $(7-4)$ \\
\hline $\mathrm{C}+2 \mathrm{H}_{2} \mathrm{O} \rightarrow \mathrm{CO}_{2}+\mathrm{H}_{2}$ & +90.2 & $(7-5)$ \\
\hline $\mathrm{C}+\mathrm{CO}_{2} \rightarrow 2 \mathrm{CO}$ & +172.4 & $(7-6)$ \\
\hline \multicolumn{3}{|l|}{ Water-gas shift reaction } \\
\hline $\mathrm{CO}+\mathrm{H}_{2} \mathrm{O} \rightarrow \mathrm{CO}_{2}+\mathrm{H}_{2}$ & -41.1 & $(7-7)$ \\
\hline \multicolumn{3}{|l|}{ Methanation } \\
\hline $2 \mathrm{CO}+2 \mathrm{H}_{2} \rightarrow \mathrm{CH}_{4}+\mathrm{CO}_{2}$ & -247.3 & $(7-8)$ \\
\hline $\mathrm{CO}+3 \mathrm{H}_{2} \rightarrow \mathrm{CH}_{4}+\mathrm{H}_{2} \mathrm{O}$ & -206.1 & $(7-9)$ \\
\hline $\mathrm{CO}_{2}+4 \mathrm{H}_{2} \rightarrow \mathrm{CH}_{4}+\mathrm{H}_{2} \mathrm{O}$ & -165.0 & $(7-10)$ \\
\hline $\mathrm{C}+2 \mathrm{H}_{2} \rightarrow \mathrm{CH}_{4}$ & -74.8 & $(7-11)$ \\
\hline
\end{tabular}

a for $\mathrm{nC}_{7} \mathrm{H}_{16}$

Table 1. Synthesis gas reactions

\subsection{Catalyst evaluation in steam gasification process in fluidized bed gasification}

The conventional $\mathrm{Ni} / \mathrm{Al}_{2} \mathrm{O}_{3}$ catalyst and $\mathrm{Ni} / \mathrm{BCC}$ catalyst available for steam reforming were used to test tar reforming performance. As mentioned in section 7.1 and discussed in section 7.3, the deposited carbon may cause for deactivating catalysts due to covering activate site of catalysts. In this section, all experiments were performed under steam injection with s/c: $0.6 \mathrm{~mol} / \mathrm{mol}$. The added steam was expected to suppress the deposited carbon on activate surface of catalysts. In this section, the effect of steam addition on tar conversion, gas yields, and carbon conversion were investigated. The reactivity both of the $\mathrm{Ni} / \mathrm{BCC}$ and $\mathrm{Ni} / \mathrm{Al}_{2} \mathrm{O}_{3}$ have been compared and discussed in detail.

In the activity tests, the formation of products were observed for $120 \mathrm{~min}$, all calculated results of the gas yields and C_gas were the average of the specific results from various 
specific sampling times, which started at 20 min after feeding biomass and then in 20 min intervals.

As illustrated in Figure 12 (a), the gas yields are shown lowest for non-catalyst, while higher gas yields have achieved for the catalysts. The great improvement of product gas for the case of $\mathrm{Ni} / \mathrm{BCC}$ catalyst should be given more attention. Most main gas components $\left(\mathrm{CH}_{4}\right.$, $\mathrm{CO}, \mathrm{CO}_{2}, \mathrm{H}_{2}$ ) were higher than those of $\mathrm{Ni} / \mathrm{Al}_{2} \mathrm{O}_{3}$ catalyst. Especially, in the case of the $\mathrm{Ni} / \mathrm{BCC}$ catalyst, $\mathrm{CO}$ and $\mathrm{H}_{2}$ yield were 10.8 and 12.3 [mmol/ g-sample daf] higher than those of the $\mathrm{Ni} / \mathrm{Al}_{2} \mathrm{O}_{3}$ catalyst. These satisfactory results could be explained by a part of the deposited carbon on the $\mathrm{Ni} / \mathrm{BCC}$ catalyst and $\mathrm{Ni} / \mathrm{BCC}$ char had been gasified in the presence of steam according to the reaction pathway as following reaction equations (Eqs. (7-4), (7-5), and (7-6)) in the Table 1.

Steam might also produce a larger active surface of Ni/BCC by steam gasification of deposited carbon on the surface of catalyst, which is also evidenced by BET data of used catalyst. After $1 \mathrm{~h}$ operation, total free surface of the $\mathrm{Ni} / \mathrm{Al}_{2} \mathrm{O}_{3}$ decreased from 104 to $32 \mathrm{~m}^{2} / \mathrm{g}$ due to reduction of nanopores by blockage of deposited carbon and catalyst particle growth. While, total free surface of Ni/BCC lightly reduced from 350 to $339 \mathrm{~m}^{2} / \mathrm{g}$, this is due to characteristic porosity of brown coal char. The results indicate that steam plays a very important factor to regenerate activity of the new catalyst by steam gasification of deposited carbon on catalyst and to significantly enhance the quality of product gas of woody biomass gasification.

Biomass carbon balance is illustrated in Figure 12 (b). It was carried out in a similar way as described in section 7.3 The blank on the top of each bar can be considered as a percentage of the C_tar which was calculated by equation 3-5 in section 7.3.

It is different from the pyrolysis process, approximately $16.5 \%$ carbon in the fresh $\mathrm{Ni} / \mathrm{BCC}$ catalyst was gasified in the presence of steam. Its percentage was defined by comparing between carbon in the fresh $\mathrm{Ni} / \mathrm{BCC}$ catalyst and carbon in used $\mathrm{Ni} / \mathrm{BCC}$ catalyst. In the presence of the $\mathrm{Ni} / \mathrm{BCC}$, biomass carbon conversion (C_gas) was calculated by subtraction between carbon of total product gas and conversion carbon of fresh $\mathrm{Ni} / \mathrm{BCC}$, which is mentioned on above. Using that method, we found that highest C_gas and lowest C_tar were achieved as 66 and $4.4 \%$ for Ni/BCC catalyst test, respectively, while the C_gas and C_tar obtained were only $59.9 \%$ and $7.4 \%$ for $\mathrm{Ni} / \mathrm{Al}_{2} \mathrm{O}_{3}$ catalyst test, respectively. Biomass tar conversion obtained was approximately $88.9 \%$ in Ni/BCC catalyst. The results indicate better catalyst activity for Ni/BCC. The detailed mechanism for this high activity is unclear at the present, however, it can be explained that some of the following characteristics of the $\mathrm{Ni} / \mathrm{BCC}$ catalyst might be associated with this activity: well distribution of nickel particles due to carbon functional group in brown coal, high porosity of the catalyst, mineral component. In addition, Tomita et al. [32] reported that in the presence of steam, tar might be absorbed on catalyst and then be gasified without forming soot. Even if carbon was formed on the catalyst surface, it could be easily gasified. He also found that the carbon deposited over nickel was rapidly gasified with hydrogen at $873 \mathrm{~K}$ by reaction $7-11$ in Table 1 [33]. This fact that can be observed both of $\mathrm{CH}_{4}$ and $\mathrm{H}_{2}$ yields are higher than that of the $\mathrm{Ni} / \mathrm{A}_{2} \mathrm{O}_{3}$ catalyst. 


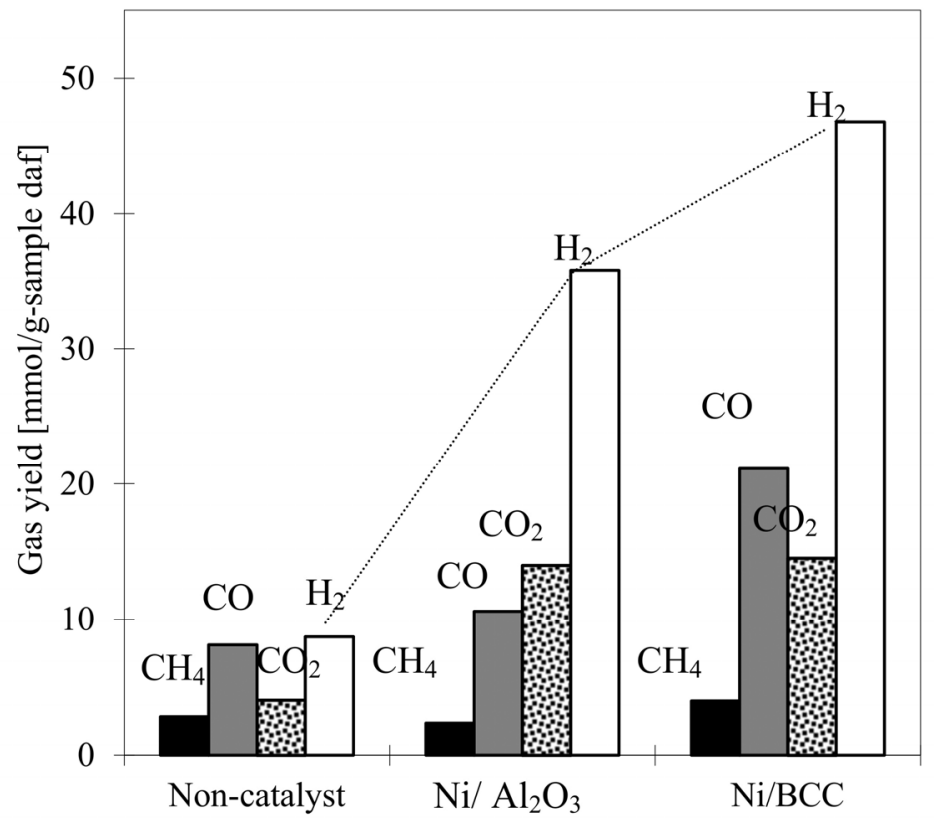

(a)

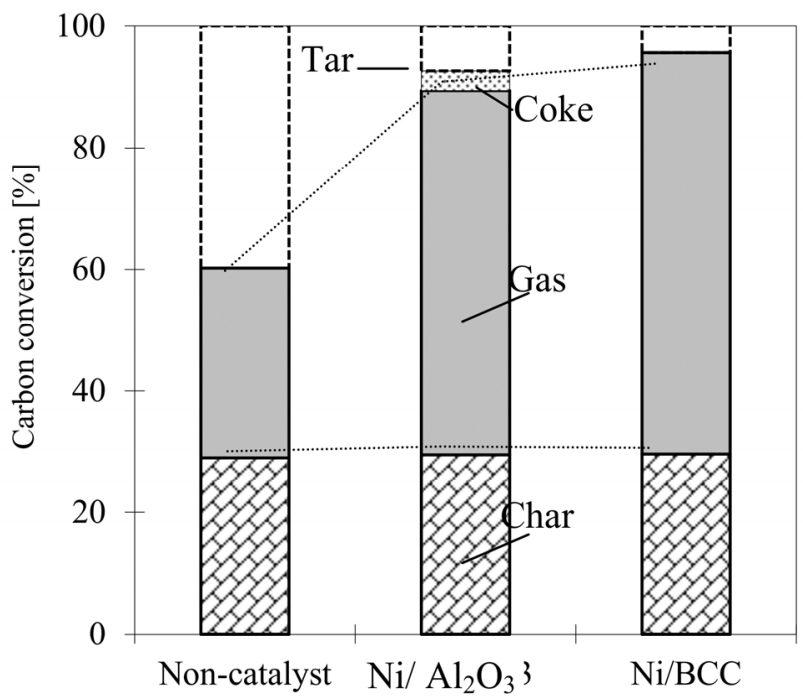

(b)

Figure 12. Comparison of different catalysts and non-catalyst in the presence of steam: (a) gas yields and (b) biomass carbon balance $(923 \mathrm{~K}, \mathrm{sv}=10000, \mathrm{~s} / \mathrm{c}=0.6)$ 


\section{Summary and conclusions}

Nickel loaded brown coal char acts a new catalyst for decomposing tar of woody biomass gasification in a two-stage fixed-bed and fluidized bed gasifier has been investigated. With the advantages of catalytic steam tar reforming is carry out at low temperature. On the other hand, catalytic reforming tar methods have significant possibilities in low temperature gasification processing for high product gas quality. This chapter attempts to a comprehensive knowledge for low temperature pyrolysis and gasification process covering study of operation conditions affecting catalytic activity behaviors of nickel loaded brown coal char catalyst.

For the effect of pyrolysis temperature on the crystalline size of nickel particle size, it is slightly affected by temperature lower than $923 \mathrm{~K}$, but great affected by temperature higher than $973 \mathrm{~K}$.

Two-stage Fixed-bed Reactor has been identified as processing the good activity even at low temperature $923 \mathrm{~K}$.

The $\mathrm{Ni} / \mathrm{BCC}$ catalyst could not perform as well as the $\mathrm{Ni} / \mathrm{Al}_{2} \mathrm{O}_{3}$ catalyst to decompose tar under pyrolysis process. However, the results show that both catalysts are good active to decompose tar from biomass pyrolysis at $923 \mathrm{~K}$.

The experimental results show a new catalyst having good catalytic activity and stability in the presence of steam at $923 \mathrm{~K}$.

In the new catalyst application with the presence of steam, $\mathrm{Ni} / \mathrm{BCC}$ catalyst exhibited more activate than conventional catalyst $\mathrm{Ni} / \mathrm{Al}_{2} \mathrm{O}_{3}$.

It was found that, catalyst has a good performance and stability at $923 \mathrm{~K}$. Approximately $89.5 \%$ of biomass tar was reformed to useful gas components $\left(\mathrm{CO}, \mathrm{H}_{2}, \mathrm{CH}_{4}\right)$.

Steam has already proved to be very important in activating the new catalyst and significantly enhances the quality of product gas of woody biomass gasification with high hydrogen concentration of product gas.

The results suggest that the $\mathrm{Ni} / \mathrm{BCC}$ catalyst offers a potential to be used as a tar steam reforming catalyst in biomass gasification.

\section{Author details}

Le Duc Dung

School of Heat Engineering and Refrigeration, Hanoi University of Science and Technology,

Vietnam

Le Duc Dung, Kayoko Morishita and Takayuki Takarada

Department of Chemical and Environmental Engineering, Gunma University Faculty of

Engineering, Japan 


\section{Acknowledgement}

We would like to express my sincere thanks to all who have contributed to this work. We would like to express my gratitude to Ms. Yukiko Ogawa for her help in performing proximate and ultimate analyses of samples. I would like to thank Mrs. Miyoko Kakuage, Mrs. Mayumi Tanaka, Dr. Xianbin Xiao, Dr. Liuyun Li and all of students in Takarada's Laboratory for their support.

I gratefully acknowledge the financial support of this work by the Project of Prefecture Collaboration of Regional Entities for the Advancement of Technological Excellence, Japan Science and Technology Agency for one and half year. Greatly, I acknowledge the financial support of this work from Asian Jinzai project, Japan Government scholarship for one and half year. We would like to acknowledge Gunma University Faculty of Engineering and Hanoi University of Science and Technology for all their support throughout this research.

\section{References}

[1] Nordgreen, T., T. Li and K. Sjostrom; Energy Fuels; 20, 290-895 (2006)

[2] Maniatis, K. and A. A. C. M. Beenackers; Biomass Bioenergy; 18, 1-4 (2000)

[3] Milne T.A. and R.J. Evans. ; US Department of Energy, (1998)

[4] Morf P., P. Hasler, T.Nussbaumer; Fuel; 81, 843-853 (2002)

[5] Han J., and H.J. Kim; Renewable and Sustainable Energy Reviews, 12, 397-416 (2008)

[6] Gil J., Corella J., M. P. Aznar, and M. A.Caballero; Biomass Bioenerg., 17, 389-403 (1999)

[7] Corma A., and A.V. Orchille's; Microporous and Mesoporous Materials; 35-36, 21-30 (2000)

[8] Dayton D. A review of the literature on catalytic biomass tar destruction; USA: National Renewable Energy Laboratory; (2002)

[9] Davidian T., N. Guilhaume , H. Provendier, and C. Mirodatos; Applied Catalysis A: General 337, 111-120 (2008)

[10] Sutton D., B. Kelleher, J. R.H. and Ross; Fuel Processing Technology; 73, 155-173 (2001)

[11] Moulijn J.A., A.E. van Diepen, and F. Kapteijn; Applied Catalysis A: General; 212, 3-16 (2001)

[12] Asadullah, M., S. Ito, K. Kunimori, M. Yamada and K. Tomishige; J. Catal.; 208, 255-259 (2002)

[13] Zhang R, Brown RC, Suby A, and Cummer K.; Energ Convers Manage; 45, 995-1014 (2004)

[14] Furusawa, T., T. Sato, H. Sugito, Y. Miura, Y. Ishiyama, M. Sato, N. Itoh and N. Suzuki; Int. J. Hydrogen Energy, 32, 699-704 (2007)

[15] Srinakruang J., K. Sato, T. Vitidsant, and K. Fujimoto; Fuel, 85, 17-18, 2419-2426 (2006)

[16] Srinakruang J., K. Sato, T. Vitidsant, and K. Fujimoto; Catal. Communic.; 6, 437-440 (2005)

[17] Sato K., K. Fujimoto; Catalysis Communications, 8, 1697-1701 (2007)

[18] Dou B, J. Gao, X. Sha, and S. W. Baek; Appl Ther Eng; 23, 2229-2239 (2003)

[19] Baker EG. Ind Eng Chem Res; 26, 1335-9 (1987) 
[20] Miyazawa T., T. Kimura, J. Nishikawa, S. Kado, K. Kunimori, K. Tomishige; Catalysis Today; 115, 254-262 (2006)

[21] Tomita, A., K. Yoshida, Y. Nishiyama and Y. Tamai; Carbon, 10, 601-606 (1972)

[22] Tomita, A. and Y. Tamai; Fuel, 60, 992-994 (1981)

[23] Tomita, A., Y. Ohtsuka and Y. Tamai; Fuel, 62, 150-154 (1983)

[24] Tomita, A., Y. Watanabe, T. Takarada, Y. Ohtsuka and Y. Tamai; Fuel, 64, 795-800 (1985)

[25] Ohtsuka Y., and A. Tomita; Fuel, 65, 1653-1657 (1986)

[26] Takarada, T., T. Tonishi, Y. Fusegawa, K. Morishita, N. Nakagawa and K. Kato; Fuel, 72, 921-926 (1993)

[27] Sato M.; Master thesis; Gunma Univer. Facul. of Eng.; (2004)

[28] D. D. Le, X. Xiao, K. Morishita and T. Takarada; J. Chem. Engineering of Japan, 42, 51-57 (2009)

[29] Bodle, W. W., and Schora, F. C. In "Advances in Coal Utilization Technology," (K. S. Vorres and W. W. Waterman, eds.), p. 11. Institute of Gas Technology, Chicago (1979)

[30] Donald L. C. Academic Press, USA, (Chapter 3, 8, and 9) (1998)

[31] K. Aasberg-Petersen, J.-H. Bak Hansen, T.S. Christensen, I. Dybkjaer, P. Seier Christensen, C. Stub Nielsen, S.E.L. Winter Madsen, and J.R. Rostrup-Nielsen; Applied Catalysis A: General; 221, 379-387 (2001)

[32] Tomita, A., Y. Watanabe, T. Takarada, Y. Ohtsuka and Y. Tamai; Fuel, 64, 795-800 (1985)

[33] Tomita, A., K. Yoshida, Y. Nishiyama and Y. Tamai; Carbon, 10, 601-606 (1972) 